\title{
Parameters Influencing Cocrystallization and Polymorphism in Milk Fat
}

\author{
Birgit Breitschuh and Erich J. Windhab* \\ Institute of Food Engineering, Department of Food Science, Swiss Federal Institute of Technology (ETH), \\ 8092 Zurich, Switzerland
}

\begin{abstract}
Dry fractionation of milk fat is a common technique used to produce fat fractions with physical properties that are suitable for a variety of food and pharmaceutical products. During milk fat fractionation, the partial crystallization of triacylglycerols from the melt is the most important step. The efficiency of the separation of the crystals from the suspension is also important, but the crystallization itself influences the chemical composition and thereby determines the properties of the crystal fraction. At low supercooling, the crystallization kinetics are slow, and thus process time is increased. With increased kinetics due to a strong supersaturation, the chemical composition of the crystals is changed compared to crystals formed under slow kinetic conditions. This study shows to what extent controlled temperature and supercooling during milk fat crystallization influence crystal amount and the physical properties of the resulting fractions. Differences of the thermal characteristics of the crystal suspensions are directly detected by differential scanning calorimetry and nuclear magnetic resonance. At slow crystallization kinetics, the melting temperature range of the crystals in the suspensions is broader, and the resolution of the melting peak is higher. It is shown that compound crystals are formed when supercooling is performed, even if the supercooling takes place only for a short period of time. Controlled temperature conditions during crystallization govern larger differences in the fatty acid and triacylglycerol composition of the liquid and of the crystalline phases, compared to fractions crystallized under supercooling conditions, which contain a high amount of compound crystals.

JAOCS 75, 897-904 (1998).
\end{abstract}

KEY WORDS: Compound crystals, crystallization, differential scanning calorimetry, fractionation, milk fat, mixed crystals, nuclear magnetic resonance, polymorphism, process control, triacylglycerol composition.

Milk fat has a heterogeneous nature. It contains a large variety of fatty acids with different chainlengths. So far, over 400 different fatty acids have been identified in milk fat (1-3). The triacylglycerol composition is even more complex because the theoretical number of possible combinations of these fatty acids in triacylglycerols is $400^{3}$. Due to its complex composition, the melting range of milk fat is broad and

*To whom correspondence should be addressed.

E-mail: erich.windhab@ilw.agrl.ethz.ch spans from about -40 to $40^{\circ} \mathrm{C}$. Furthermore, the composition changes with season, region, and feeding (4). These physical properties and variations restrict the use of milk fat in food and pharmaceutical or cosmetic products. To overcome these limitations, fractionation is performed (5). The techniques used for fractionation are varied. They are reviewed by Kreulen (6), Deffense (7), and Hamm (8). The most common dry fractionation is the separation of triacylglycerols on the basis of their melting ranges. A single-step fractionation yields a hard and a soft fraction, which are called stearin and olein, respectively.

Dry fractionation consists of two steps, a partial crystallization of triacylglycerols from a melt and a subsequent separation. The resulting differences in the fractions depend on the process characteristics and parameter settings. The efficiency of separation of the liquid (olein) from the crystalline phase (stearin) influences the quality of the solid fraction to a great extent. The more liquid is removed, the greater are the differences in the solid fraction, compared to the original milk fat $(7,9)$. The crystallization step has a greater influence on the chemical composition of the pure fractions.

Crystallization in general can be divided into two characteristic process steps: nucleation and growth. To crystallize a fat compound, supersaturation or supercooling is necessary. This is the driving force for both crystallization steps (10).

For fat systems, crystallization is complex because natural fats are a mixture of various triacylglycerols. Consequently, the concentration of each triacylglycerol is low and, for example, increased supercooling is needed to achieve nucleation of this low concentrated species.

Furthermore, triacylglycerols are characterized by a complex melting behavior. They can solidify in three different crystal structures $\left(\alpha, \beta^{\prime}, \beta\right)$ (polymorphism). Different crystal grid structures result depending on the magnitude of the driving force of crystallization. Less stable modifications require a lower driving force. The different polymorphic modifications have different thermodynamic stability, and the metastable polymorphic modifications $\left(\alpha, \beta^{\prime}\right)$ are transformed with time to the stable $\beta$ form.

In a multicomponent fat, such as milk fat, compound crystals can easily be formed due to the low supersaturation of one triacylglycerol (11). Compound or mixed crystals are composed of different molecular species, favored by similar 
chainlength of the fatty acids (12). Preferably, they form metastable modifications because the crystal lattice is not very dense. Compound crystals cause a narrow melting range and a higher crystal fraction (13); furthermore, unstable polymorphic forms $\left(\alpha, \beta^{\prime}\right)$ may persist almost indefinitely.

Due to its complex composition, the crystallization of triacylglycerols in milk fat and milk fat fractions is not well known (14). If the temperature is gradually decreased, successive crystallization of triacylglycerols occurs. The parameters that influence crystallization and the properties of the final fractions consist of the degree of supercooling, temperature, and residence time.

The aim of this study is to determine the effect of crystallization temperature and supercooling on the physical and chemical characteristics of the resulting milk fat fractions. The investigations are based on direct measurements of the calorimetric properties of a crystal suspension, thus detecting crystal temperature memory as well as the crystal amount in a suspension.

\section{MATERIALS AND METHODS}

Sample. Anhydrous milk fat was obtained from Aargauer Zentralmolkerei Suhr (Suhr, Switzerland). The melting point of the milk fat was $35^{\circ} \mathrm{C}$ [corresponding to less than $1.5 \%$ solid fat content measured by nuclear magnetic resonance (NMR) (15)]. The fatty acid composition of the milk fat is given in Table 1, and the triacylglycerol composition is given in Table 2.

Standardized preparation of crystal suspensions. The milk fat was crystallized in a rheometer (Bohlin Visco 88; Bohlin Instruments Inc., Cranbury NJ; Searle principle) at defined temperatures and a constant shear rate of $1041 \mathrm{~s}^{-1}$ until an equilibrium state was reached. Further information is provided elsewhere (16).

Separation into milk fat fractions. To analyze the resulting fractions, the crystal suspensions were filtered in a pressure filter (BHS, Sonthofen, Germany). The equilibrated crystal suspensions (created in the rheometer) were filtered $15 \mathrm{~min}$ at 1.5 bar, and the filter medium used was Nybolt PA 1/1/C (Sefar Inc., Heiden, Switzerland) with a pore size of $1 \mu \mathrm{m}$.

Calorimetric measurements. The calorimeter used was a DSC Gold+ (Rheometric Scientific GmbH, Bensheim, Germany) with an accuracy of $1 \mu \mathrm{W}$. Gallium $[h=18.95 \mathrm{cal} / \mathrm{g}$, $T$ (melting) $=29.765^{\circ} \mathrm{C}$ ] was used for temperature and enthalpy calibration, and the instrument was calibrated at $10^{\circ} \mathrm{C} / \mathrm{min}$. Aluminum pans were used, and the sample weight was about $1-5 \mathrm{mg}$. One drop of a crystal suspension was inserted into an empty pan and immediately (within seconds) measured at a constant heating rate of $10^{\circ} \mathrm{C} / \mathrm{min}$, registering the heating curve. As a reference, an empty pan was measured at the same time. For analysis of the heat of fusion, the area between the heat flow curve and the extrapolated baseline was determined. The cooling was performed by using liquid nitrogen as refrigerant. Further details are provided elsewhere (16).

Nuclear magnetic resonance. The instrument used in these investigations was a Minispec NMS 120 (Spectrospin, Bruker Analytical and Medical Instruments, Fällanden, Switzerland). The solid fat content was measured directly from the crystal suspensions (16).

Gas chromatography. The fatty acid composition was determined as methyl esters by gas chromatography (HP 6890, FID, Hewlett-Packard, Basel, Switzerland) on an SGE BPX70 (Infochroma, Zug, Switzerland) column. The triacylglycerol composition was analyzed in a gas chromatograph (HP 6890) with an apolar column (J\&W DB-5HT, MSP Friedi, Koeniz, Switzerland). The fat was diluted in heptane. The results are expressed as mean average weight percentages on a fatty acid or triacylglycerol basis, respectively (17-19).

\section{RESULTS}

Crystallization kinetics. Because milk fat is a multicomponent fat, the amount of triacylglycerols that crystallizes is mainly dependent on the crystallization temperature. In a rheometer for reproducible simulation of a crystallization

TABLE 1

Fatty Acid Composition of Milk Fat and Separated Suspensions Crystallized in a Rheometer Directly at Fractionation Temperature ${ }^{a}$

\begin{tabular}{|c|c|c|c|c|c|c|c|c|c|c|c|}
\hline & Milk fat & $\begin{array}{c}\text { Stearin } 34^{\circ} \mathrm{C} \\
\left(34^{\circ} \mathrm{C}\right)\end{array}$ & $\begin{array}{c}\text { Olein } 34^{\circ} \mathrm{C} \\
\left(34^{\circ} \mathrm{C}\right)\end{array}$ & $\begin{array}{c}\text { Stearin } 32^{\circ} \mathrm{C} \\
\left(32^{\circ} \mathrm{C}\right)\end{array}$ & $\begin{array}{c}\text { Olein } 32^{\circ} \mathrm{C} \\
\left(32^{\circ} \mathrm{C}\right)\end{array}$ & $\begin{array}{c}\text { Stearin } 30^{\circ} \mathrm{C} \\
\left(30^{\circ} \mathrm{C}\right)\end{array}$ & $\begin{array}{c}\text { Olein } 30^{\circ} \mathrm{C} \\
\left(30^{\circ} \mathrm{C}\right)\end{array}$ & $\begin{array}{c}\text { Stearin } 28^{\circ} \mathrm{C} \\
\left(28^{\circ} \mathrm{C}\right)\end{array}$ & $\begin{array}{c}\text { Olein } 28^{\circ} \mathrm{C} \\
\left(28^{\circ} \mathrm{C}\right)\end{array}$ & $\begin{array}{c}\text { Stearin } 26^{\circ} \mathrm{C} \\
\left(26^{\circ} \mathrm{C}\right)\end{array}$ & $\begin{array}{c}\text { Olein } 26^{\circ} \mathrm{C} \\
\left(26^{\circ} \mathrm{C}\right)\end{array}$ \\
\hline Butyric acid & 4.10 & 3.00 & 4.40 & 2.90 & 4.50 & 3.10 & 4.70 & 3.60 & 4.80 & 3.30 & 4.80 \\
\hline Caproic acid & 2.40 & 1.70 & 2.50 & 1.70 & 2.60 & 1.80 & 2.70 & 2.00 & 2.70 & 1.90 & 2.70 \\
\hline Caprylic acid & 1.30 & 1.00 & 1.40 & 0.90 & 1.40 & 1.00 & 1.40 & 1.10 & 1.50 & 1.10 & 1.50 \\
\hline Capric acid & 2.70 & 2.10 & 2.80 & 2.10 & 2.80 & 2.30 & 2.80 & 2.40 & 2.80 & 2.40 & 2.90 \\
\hline Lauric acid & 3.20 & 2.90 & 3.30 & 2.90 & 3.30 & 3.10 & 3.30 & 3.20 & 3.30 & 3.20 & 3.30 \\
\hline Myristic acid & 10.50 & 10.90 & 10.50 & 11.00 & 10.40 & 11.20 & 10.30 & 11.10 & 10.20 & 11.30 & 10.10 \\
\hline Palmitic acid & 27.60 & 33.20 & 27.30 & 32.80 & 26.60 & 32.40 & 26.30 & 31.00 & 25.90 & 31.20 & 25.80 \\
\hline Margaric acid & 0.70 & 0.90 & 0.70 & 0.90 & 0.70 & 0.90 & 0.70 & 0.80 & 0.70 & 0.80 & 0.70 \\
\hline Stearic acid & 10.60 & 15.40 & 10.20 & 14.80 & 9.70 & 14.30 & 9.50 & 13.10 & 9.40 & 13.20 & 9.30 \\
\hline Oleic acid & 25.50 & 19.90 & 25.70 & 20.00 & 26.60 & 20.40 & 27.00 & 21.50 & 27.20 & 21.60 & 27.30 \\
\hline Linoleic acid & 2.00 & 1.60 & 2.00 & 1.70 & 2.10 & 1.60 & 1.90 & 1.80 & 2.10 & 1.80 & 2.10 \\
\hline Linolenic acid & 0.90 & 0.70 & 1.00 & 0.70 & 1.00 & 0.70 & 1.00 & 0.80 & 1.10 & 0.70 & 1.10 \\
\hline Arachidic acid & 0.90 & 0.80 & 0.80 & 0.80 & 0.80 & 0.60 & 0.80 & 0.60 & 0.90 & 0.60 & 0.90 \\
\hline
\end{tabular}

${ }^{a}$ Concentrations given in wt\% of total fatty acid methyl ester content. 
TABLE 2

Triacylglycerol Composition of Milk Fat and Separated Suspensions Crystallized in a Rheometer Directly at Fractionation Temperature ${ }^{a}$

\begin{tabular}{|c|c|c|c|c|c|c|c|c|c|c|c|}
\hline & Milk fat & $\begin{array}{c}\text { Stearin } 34^{\circ} \mathrm{C} \\
\left(34^{\circ} \mathrm{C}\right)\end{array}$ & $\begin{array}{c}\text { Olein } 34^{\circ} \mathrm{C} \\
\left(34^{\circ} \mathrm{C}\right)\end{array}$ & $\begin{array}{c}\text { Stearin } 32^{\circ} \mathrm{C} \\
\left(32^{\circ} \mathrm{C}\right)\end{array}$ & $\begin{array}{c}\text { Olein } 32^{\circ} \mathrm{C} \\
\left(32^{\circ} \mathrm{C}\right)\end{array}$ & $\begin{array}{c}\text { Stearin } 30^{\circ} \mathrm{C} \\
\left(30^{\circ} \mathrm{C}\right)\end{array}$ & $\begin{array}{c}\text { Olein } 30^{\circ} \mathrm{C} \\
\left(30^{\circ} \mathrm{C}\right)\end{array}$ & $\begin{array}{c}\text { Stearin } 28^{\circ} \mathrm{C} \\
\left(28^{\circ} \mathrm{C}\right)\end{array}$ & $\begin{array}{c}\text { Olein } 28^{\circ} \mathrm{C} \\
\left(28^{\circ} \mathrm{C}\right)\end{array}$ & $\begin{array}{c}\text { Stearin } 26^{\circ} \mathrm{C} \\
\left(26^{\circ} \mathrm{C}\right)\end{array}$ & $\begin{array}{c}\text { Olein } 26^{\circ} \mathrm{C} \\
\left(26^{\circ} \mathrm{C}\right)\end{array}$ \\
\hline $\mathrm{C}_{24}$ & 0.06 & 0.04 & 0.06 & 0.03 & 0.05 & 0.03 & 0.06 & 0.04 & 0.05 & 0.03 & 0.06 \\
\hline Cholesterol & 0.32 & 0.23 & 0.32 & 0.21 & 0.32 & 0.22 & 0.34 & 0.25 & 0.34 & 0.23 & 0.34 \\
\hline $\mathrm{C}_{26}$ & 0.28 & 0.20 & 0.27 & 0.17 & 0.24 & 0.19 & 0.29 & 0.21 & 0.28 & 0.17 & 0.27 \\
\hline $\mathrm{C}_{28}$ & 0.62 & 0.43 & 0.62 & 0.39 & 0.57 & 0.41 & 0.64 & 0.47 & 0.65 & 0.41 & 0.64 \\
\hline $\mathrm{C}_{30}$ & 1.12 & 0.81 & 1.15 & 0.74 & 1.11 & 0.79 & 1.20 & 0.90 & 1.21 & 0.81 & 1.20 \\
\hline $\mathrm{C}_{32}$ & 2.31 & 1.60 & 2.34 & 1.57 & 2.33 & 1.66 & 2.48 & 1.82 & 2.48 & 1.73 & 2.48 \\
\hline $\mathrm{C}_{34}$ & 5.39 & 3.89 & 5.65 & 3.83 & 5.78 & 4.03 & 5.85 & 4.32 & 6.02 & 4.20 & 6.06 \\
\hline $\mathrm{C}_{36}$ & 10.33 & 7.17 & 10.53 & 7.17 & 10.91 & 7.53 & 11.08 & 8.29 & 11.27 & 8.00 & 11.35 \\
\hline $\mathrm{C}_{38}$ & 12.25 & 8.71 & 12.77 & 8.70 & 13.24 & 9.06 & 13.52 & 9.85 & 13.49 & 9.80 & 13.60 \\
\hline $\mathrm{C}_{40}$ & 9.78 & 7.02 & 9.96 & 7.04 & 10.31 & 7.50 & 10.53 & 8.08 & 10.73 & 7.98 & 10.81 \\
\hline $\mathrm{C}_{42}$ & 6.52 & 5.56 & 6.67 & 5.60 & 6.67 & 5.82 & 6.70 & 6.06 & 6.70 & 6.12 & 6.72 \\
\hline $\mathrm{C}_{44}$ & 5.84 & 6.12 & 5.81 & 6.35 & 5.72 & 6.58 & 5.59 & 6.46 & 5.49 & 6.68 & 5.41 \\
\hline $\mathrm{C}_{46}$ & 6.96 & 9.40 & 6.67 & 9.59 & 6.41 & 9.31 & 6.20 & 8.86 & 5.99 & 9.05 & 5.90 \\
\hline$C_{48}$ & 9.13 & 13.13 & 8.73 & 13.17 & 8.41 & 12.80 & 8.02 & 11.74 & 7.83 & 11.88 & 7.73 \\
\hline $\mathrm{C}_{50}$ & 11.90 & 16.61 & 11.60 & 16.37 & 11.17 & 15.65 & 10.86 & 14.58 & 10.72 & 14.99 & 10.65 \\
\hline$C_{52}$ & 11.43 & 13.30 & 11.05 & 13.41 & 11.01 & 12.91 & 10.98 & 12.48 & 10.90 & 12.43 & 10.85 \\
\hline$C_{54}$ & 5.75 & 5.80 & 5.80 & 5.66 & 5.76 & 5.51 & 5.67 & 5.54 & 5.85 & 5.48 & 5.94 \\
\hline
\end{tabular}

${ }^{a}$ Concentrations given in $\mathrm{wt} \%$ of total triacylglycerol content.

process under well-defined shear flow conditions, the crystallization can be monitored by the related viscosity changes vs. time (16). After reaching a temperature equilibrium, the Newtonian milk fat melt shows a constant viscosity until nucleation starts, and the viscosity increases with the crystallizations progress (Fig. 1). When crystallization is almost finished, a constant viscosity is reached. We found that on a long time scale (several hours), an additional $0.5 \%$ of triacylglycerols crystallizes until equilibrated at this temperature.

Crystallizing milk fat at a constant shear rate of $1041 \mathrm{~s}^{-1}$, the viscosity increase due to crystallization is faster at a lower temperature (Fig. 1). At low temperatures, the high-melting triacylglycerols are more strongly supercooled, and thus the crystallization kinetics are faster. Crystallization is also finished earlier due to the increased kinetics under supercooling and the higher amount of crystallizable triacylglycerols. The final plateau viscosity is higher at lower crystallization temperatures because more triacylglycerols are supercooled and crystallize. Table 3 gives an overview of the directly measured specific heat of fusion [measured by differential

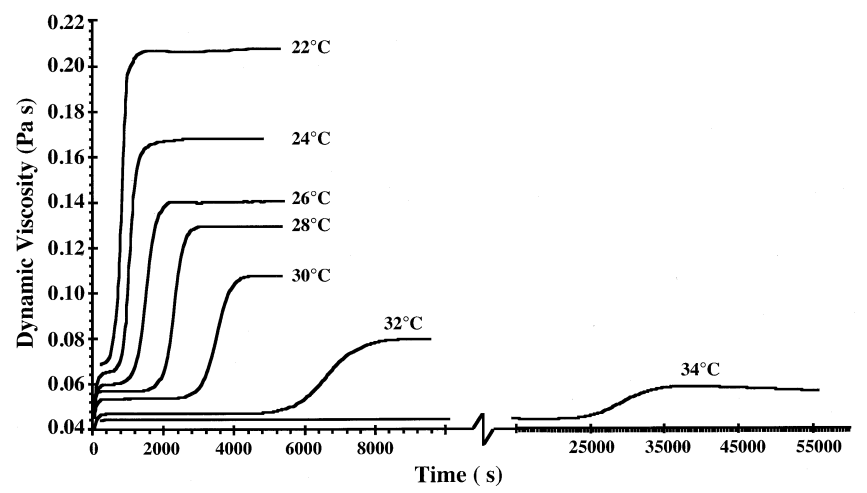

FIG. 1. Viscosity as a function of time at a constant shear rate of $1041 \mathrm{~s}^{-1}$ and different constant temperatures (couette, $1.25 \mathrm{~mm}$ gap). scanning calorimetry (DSC)] and the crystal amount (measured by NMR) of the suspensions that were crystallized at a constant shear rate of $1041 \mathrm{~s}^{-1}$ at different constant temperatures.

At a lower crystallization temperature, the stronger supercooling of the higher-melting triacylglycerols may cause the formation of unstable polymorphic crystal lattices (20). Furthermore, as shown by different researchers $(12,13)$, with stronger supercooling, triacylglycerols of similar chainlength may form compound crystals. These phenomena result in a narrowed melting range, which will be slightly shifted to lower temperatures $(13,21)$.

Melting characteristics. Figure 2 shows the melting curves of equilibrated milk fat suspensions that were crystallized directly at the crystallization temperature. The lower the crystallization temperature, the higher the heat of fusion, as shown by the increase of the area below the baseline (normalized heat flow). The beginning of melting (onset temperature) is decreased at lower crystallization temperatures (Table 3), which govern crystallization of lower-melting triacylglyc-

TABLE 3

Solid Fat Content, Heat of Fusion, Onset and Offset Temperatures, and Standard Deviations of Milk Fat Suspensions Directly Crystallized at the Listed Temperatures Until an Equilibrium Was Reached at a Constant Shear Rate of $1041 \mathrm{~s}^{-1}$

\begin{tabular}{lcccc}
\hline $\begin{array}{l}\text { Crystallization } \\
\text { temperature } \\
\left({ }^{\circ} \mathrm{C}\right)\end{array}$ & $\begin{array}{c}\text { Solid fat } \\
\text { content } \\
(\%)\end{array}$ & $\begin{array}{c}\text { Heat } \\
\text { of fusion } \\
(\mathrm{J} / \mathrm{g})\end{array}$ & $\begin{array}{c}\text { Onset } \\
\text { temperature } \\
\left({ }^{\circ} \mathrm{C}\right)\end{array}$ & $\begin{array}{c}\text { Offset } \\
\text { temperature } \\
\left({ }^{\circ} \mathrm{C}\right)\end{array}$ \\
\hline 26 & $9.50(0.14)^{a}$ & $12.50(0.31)$ & $27.49(0.44)$ & $44.18(0.78)$ \\
28 & $7.24(0.23)$ & $9.99(0.09)$ & $29.09(0.43)$ & $44.68(0.95)$ \\
30 & $5.45(0.02)$ & $7.80(0.24)$ & $31.29(0.33)$ & $44.70(1.86)$ \\
32 & $4.14(0.09)$ & $4.85(0.45)$ & $33.34(0.58)$ & $44.21(1.08)$ \\
34 & $2.41(0.11)$ & $2.49(0.29)$ & $35.45(0.30)$ & $44.39(0.69)$ \\
\hline
\end{tabular}

${ }^{a}$ Numbers in parentheses are standard deviations in the same units as the data. 


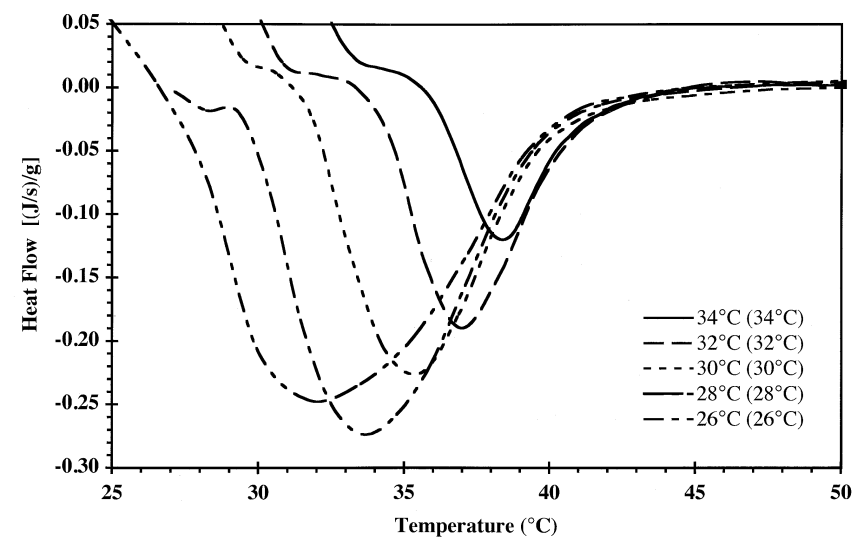

FIG. 2. Melting curves of temperature-equilibrated milk fat suspensions crystallized directly at crystallization temperature.

erols. Furthermore, the maximum melting of the crystals is shifted to lower temperatures. At a lower crystallization temperature, higher-melting triacylglycerols are more strongly supercooled, which means that more unstable polymorphic modifications appear (20). At the same time, stronger supercooling benefits compound crystallization of triacylglycerols with similar chainlengths. These effects result in decreased melting temperatures.

When crystallizing milk fat until equilibrium at $34^{\circ} \mathrm{C}$, the crystallization kinetics are slow due to the low amount of triacylglycerols that may crystallize (2.4\%, Table 3$)$ and due to the low supercooling of these triacylglycerols. The crystallization takes place over about $9 \mathrm{~h}$ (Fig. 1). After temperature equilibrium at $34^{\circ} \mathrm{C}$, the crystallization temperature of the suspension is decreased by $2^{\circ} \mathrm{C}$ under continuous shearing until equilibrated at the new crystallization temperature $\left(32^{\circ} \mathrm{C}\right)$. By decreasing the temperature further triacylglycerols are supercooled. Because the higher-melting crystals, which already exist in the suspension, serve as nuclei, crystallization time is lowered. The newly crystallized triacylglycerols grow around the existing crystals in the suspension; no nucleation needs to take place (22). This stepwise crystallization is performed from 34 to $26^{\circ} \mathrm{C}$.

The melting curves of these stepwise crystallized milk fat suspensions are shown in Figure 3. Due to the temperature decrease in the suspension and further growth of the existing crystals, the temperature range of melting is only changed in the onset temperature, which here is lowered (Table 4). The off-set temperature of the crystal suspensions stays constant by further crystallization (larger crystal amounts in the suspensions). By decreasing the temperature stepwise, a second maximum $\left(\sim 32^{\circ} \mathrm{C}\right)$ of melting appears in the suspension. The triacylglycerols with a melting range between 34 and $26^{\circ} \mathrm{C}$ appear to be soluble.

If crystallization takes place at $26^{\circ} \mathrm{C}$, at higher supercooling of the highest-melting triacylglycerols, less stable modifications of the triacylglycerols are formed, as well as compound crystals due to the stronger supercooling. Figure 4 shows the melting curves of the crystal suspensions that were

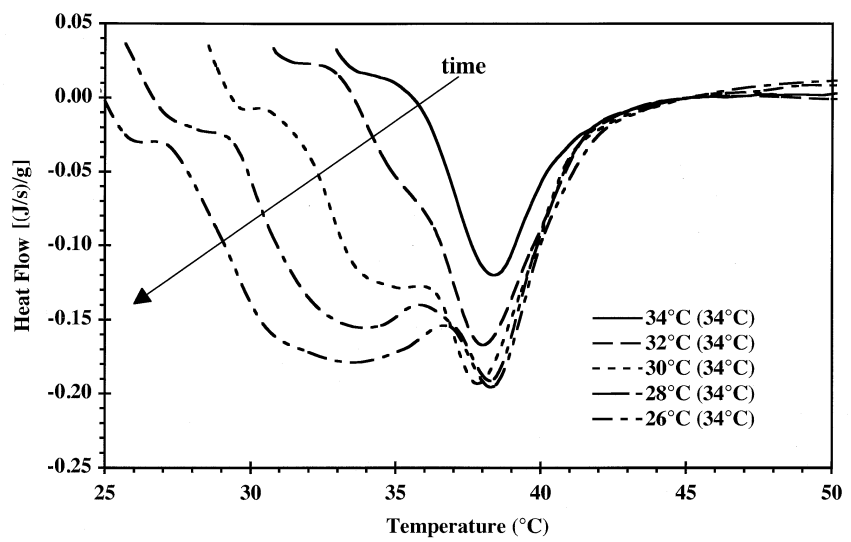

FIG. 3. Melting curves of temperature-equilibrated milk fat suspensions crystallized under decreasing temperatures stepwise from $34^{\circ} \mathrm{C}$ down to $26^{\circ} \mathrm{C}$.

crystallized at $26^{\circ} \mathrm{C}$ and stepwise melted to the final equilibrium temperature. Only one melting maximum occurs when nucleation is performed at strong supercooling $\left(26^{\circ} \mathrm{C}\right)$. This melting maximum is then shifted to a lower temperature, compared to the slow and stepwise crystallized suspensions shown in Figure 3. The melting range is also narrowed. By raising the temperature, the crystals with a melting point between $26^{\circ} \mathrm{C}$ and the new temperature will melt. Therefore, the onset temperature increases (Table 5).

Focusing on the two extreme temperatures $\left(26\right.$ and $\left.34^{\circ} \mathrm{C}\right)$, crystallized by slow temperature decrease or at low temperature and partially melted, respectively, the differences are obvious (Figs. 3 and 4). The solid fat content is $2.3 \%$ higher in the supercooled suspension, and the heat of fusion is $1.3 \mathrm{~J} / \mathrm{g}$ higher (Tables 4 and 5). A second maximum in the slow, stepwise crystallized sample exists (Fig. 3) at a lower temperature. In the $34^{\circ} \mathrm{C}$ suspensions, the differences in solid fat content and heat of fusion are small and stay within the standard deviation. The direct, slowly crystallized suspension shows a slightly higher melting maximum, compared to the sample where nucleation took place at $26^{\circ} \mathrm{C}$. The differences in the melting characteristics may indicate different polymorphic modifications of the crystallized triacylglycerols. But on a long time scale (several days), no polymorphic transforma-

\section{TABLE 4}

Solid Fat Content, Heat of Fusion, Onset and Offset Temperatures, and Standard Deviations of Temperature Equilibrated Crystal Suspensions Crystallized Under Decreasing Temperatures from $34^{\circ} \mathrm{C}$ Down to $26^{\circ} \mathrm{C}$

\begin{tabular}{lcccc}
\hline $\begin{array}{l}\text { Crystallization } \\
\text { temperature } \\
\left({ }^{\circ} \mathrm{C}\right)\end{array}$ & $\begin{array}{c}\text { Solid fat } \\
\text { content } \\
(\%)\end{array}$ & $\begin{array}{c}\text { Heat } \\
\text { of fusion } \\
(\mathrm{J} / \mathrm{g})\end{array}$ & $\begin{array}{c}\text { Onset } \\
\text { temperature } \\
\left({ }^{\circ} \mathrm{C}\right)\end{array}$ & $\begin{array}{c}\text { Offset } \\
\text { temperature } \\
\left({ }^{\circ} \mathrm{C}\right)\end{array}$ \\
\hline \multirow{2}{26}{} & $7.16(0.12)^{a}$ & $11.24(0.25)$ & $27.07(0.08)$ & $45.21(0.52)$ \\
28 & $5.67(0.27)$ & $8.96(0.49)$ & $29.00(0.15)$ & $44.77(0.88)$ \\
30 & $5.11(0.24)$ & $6.84(0.37)$ & $31.11(0.18)$ & $45.24(0.52)$ \\
32 & $3.77(0.11)$ & $4.75(0.16)$ & $32.95(0.24)$ & $44.78(1.19)$ \\
34 & $2.41(0.11)$ & $2.49(0.29)$ & $35.45(0.30)$ & $44.39(0.69)$ \\
\hline
\end{tabular}

${ }^{a}$ Numbers in parentheses are standard deviations in the same units as the data. 


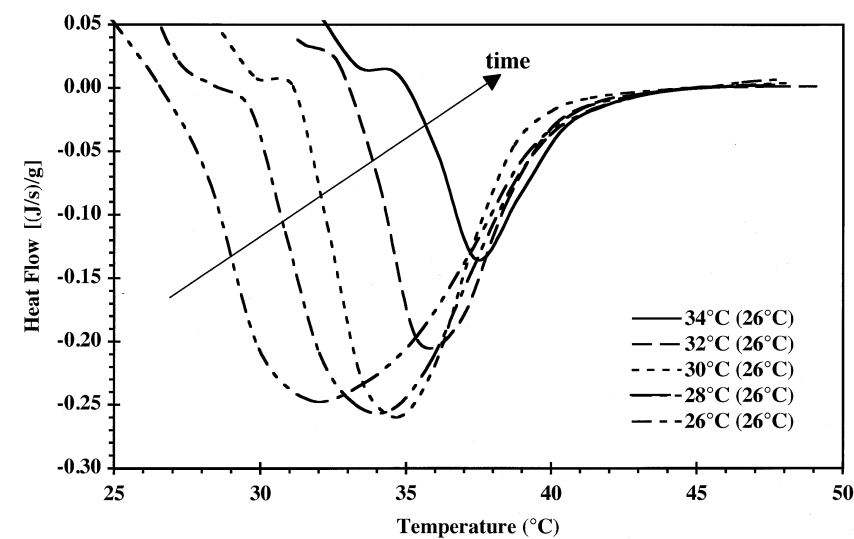

FIG. 4. Melting curves of temperature-equilibrated milk fat suspensions fast cooled until equilibrium at $26^{\circ} \mathrm{C}$ and then melted by increasing temperature stepwise up to $34^{\circ} \mathrm{C}$.

tions take place. As shown elsewhere (23), in a multicomponent fat, even the $\alpha$-form may persist almost indefinitely. Because the solid fat content of the suspensions differs between slow and strongly cooled samples, cocrystallization of similar triacylglycerols may take place.

Chemical composition. The suspensions are separated by pressure filtration into liquid and crystalline fractions for further analytical characterization. The triacylglycerol and fatty acid composition of the separated fractions is determined by gas chromatography. The differences of the amount of each triacylglycerol between the original milk fat and the fractions have been compared. The detailed data of the triacylglycerol contents in the fractions are given in Tables 2, 6, and 7, and the fatty acid compositions are given in Tables 1,8 , and 9 .

In Figure 5, a comparison is given between the separated fractions of a final crystallization temperature of $34^{\circ} \mathrm{C}$, crystallized directly at $34^{\circ} \mathrm{C}$, and stepwise melted from $26^{\circ} \mathrm{C}$, respectively. One can see at once an enrichment of long-chain
TABLE 5

Solid Fat Content, Heat of Fusion, Onset and Offset Temperatures, and Standard Deviations of Temperature Equilibrated Crystal Suspensions Fast Cooled Until Equilibrium at $26^{\circ} \mathrm{C}$ and Then Stepwise Melted by Increasing Temperatures Up to $34^{\circ} \mathrm{C}$

\begin{tabular}{lcccc}
\hline $\begin{array}{l}\text { Crystallization } \\
\text { temperature } \\
\left({ }^{\circ} \mathrm{C}\right)\end{array}$ & $\begin{array}{c}\text { Solid fat } \\
\text { content } \\
(\%)\end{array}$ & $\begin{array}{c}\text { Heat } \\
\text { of fusion } \\
\mathrm{J} / \mathrm{g})\end{array}$ & $\begin{array}{c}\text { Onset } \\
\text { temperature } \\
\left({ }^{\circ} \mathrm{C}\right)\end{array}$ & $\begin{array}{c}\text { Offset } \\
\text { temperature } \\
\left({ }^{\circ} \mathrm{C}\right)\end{array}$ \\
\hline $\begin{array}{l}26 \\
28\end{array}$ & $9.50(0.14)^{\mathrm{a}}$ & $12.50(0.31)$ & $27.49(0.44)$ & $44.18(0.78)$ \\
30 & $5.26(0.16)$ & $10.93(0.55)$ & $29.10(0.24)$ & $43.50(1.08)$ \\
32 & $4.63(0.20)$ & $8.12(0.52)$ & $30.93(0.27)$ & $43.77(1.12)$ \\
$\mathbf{\square}$ & $2.62(0.14)$ & $5.74(0.13)$ & $32.62(0.06)$ & $42.45(1.32)$ \\
\hline
\end{tabular}

${ }^{a}$ Numbers in parentheses are standard deviations in the same units as the data.

triacylglycerols $\left(\mathrm{C}_{54}\right.$ to $\left.\mathrm{C}_{44}\right)$ in the crystalline fractions (stearin), and a decreased amount of the triacylglycerols $\mathrm{C}_{42}$ to $\mathrm{C}_{24}$. The opposite is observed in the liquid fractions (olein).

When crystallization is performed at $34^{\circ} \mathrm{C}$ without any supercooling, the differences in the triacylglycerol composition, compared to milk fat, is $4.8 \%$ maximum. If nucleation takes place at high supercooling $\left(26^{\circ} \mathrm{C}\right)$, the differences in concentration between the crystalline fraction and the original milk fat are just around half the amount of the slowly crystallized sample. The error in the fatty acid and triacylglycerol measurements is below $1 \%$ of the measured value. The differences in the solid fat content are within the standard deviation (Tables 4 and 5). No large differences are found in the liquid fraction (Fig. 5) due to the separation of just $2.4 \%$ of crystals from the milk fat melt (Table 4). The same tendency occurs as in the solid fraction. Approximately $0.5 \%$ of changes in the triacylglycerol composition can be reached if the crystallization is controlled. The differences in the fatty acid composition of the fractions show similar tendencies (Tables 8 and 9). It is further shown that stearic and palmitic

TABLE 6

Triacylglycerol Composition of Separated Suspensions Crystallized in a Rheometer at $34^{\circ} \mathrm{C}$ and Stepwise Cooled to Fractionation Temperature ${ }^{a}$

\begin{tabular}{|c|c|c|c|c|c|c|c|c|c|c|}
\hline & $\begin{array}{c}\text { Olein } 34^{\circ} \mathrm{C} \\
\left(34^{\circ} \mathrm{C}\right)\end{array}$ & $\begin{array}{c}\text { Stearin } 34^{\circ} \mathrm{C} \\
\left(34^{\circ} \mathrm{C}\right)\end{array}$ & $\begin{array}{c}\text { Olein } 32^{\circ} \mathrm{C} \\
\left(34^{\circ} \mathrm{C}\right)\end{array}$ & $\begin{array}{c}\text { Stearin } 32^{\circ} \mathrm{C} \\
\left(34^{\circ} \mathrm{C}\right)\end{array}$ & $\begin{array}{c}\text { Olein } 30^{\circ} \mathrm{C} \\
\left(34^{\circ} \mathrm{C}\right)\end{array}$ & $\begin{array}{c}\text { Stearin } 30^{\circ} \mathrm{C} \\
\left(34^{\circ} \mathrm{C}\right)\end{array}$ & $\begin{array}{c}\text { Olein } 28^{\circ} \mathrm{C} \\
\left(34^{\circ} \mathrm{C}\right)\end{array}$ & $\begin{array}{c}\text { Stearin } 28^{\circ} \mathrm{C} \\
\left(34^{\circ} \mathrm{C}\right)\end{array}$ & $\begin{array}{c}\text { Olein } 26^{\circ} \mathrm{C} \\
\left(34^{\circ} \mathrm{C}\right)\end{array}$ & $\begin{array}{c}\text { Stearin } 26^{\circ} \mathrm{C} \\
\left(34^{\circ} \mathrm{C}\right)\end{array}$ \\
\hline $\mathrm{C}_{24}$ & 0.06 & 0.04 & 0.05 & 0.04 & 0.06 & 0.03 & 0.07 & 0.03 & 0.05 & 0.03 \\
\hline Cholesterol & 0.32 & 0.23 & 0.32 & 0.23 & 0.33 & 0.17 & 0.34 & 0.20 & 0.33 & 0.18 \\
\hline $\mathrm{C}_{26}$ & 0.27 & 0.20 & 0.27 & 0.16 & 0.27 & 0.13 & 0.30 & 0.15 & 0.24 & 0.12 \\
\hline $\mathrm{C}_{28}$ & 0.62 & 0.43 & 0.60 & 0.50 & 0.61 & 0.31 & 0.67 & 0.35 & 0.59 & 0.37 \\
\hline$C_{30}^{20}$ & 1.15 & 0.81 & 1.16 & 0.78 & 1.17 & 0.58 & 1.22 & 0.68 & 1.14 & 0.62 \\
\hline$C_{32}$ & 2.34 & 1.60 & 2.37 & 1.54 & 2.39 & 1.24 & 2.50 & 1.46 & 2.40 & 1.28 \\
\hline$C_{34}$ & 5.65 & 3.89 & 5.75 & 3.65 & 5.71 & 3.03 & 5.83 & 3.55 & 5.81 & 3.16 \\
\hline$C_{36}$ & 10.53 & 7.17 & 10.74 & 6.72 & 10.99 & 5.66 & 11.18 & 6.73 & 11.08 & 5.86 \\
\hline$C_{38}$ & 12.77 & 8.71 & 12.90 & 8.04 & 13.06 & 6.81 & 13.27 & 8.19 & 13.57 & 7.13 \\
\hline$C_{40}$ & 9.96 & 7.02 & 10.23 & 6.68 & 10.35 & 5.77 & 10.51 & 6.71 & 10.61 & 5.93 \\
\hline $\mathrm{C}_{42}$ & 6.67 & 5.56 & 6.67 & 5.40 & 6.71 & 5.01 & 6.76 & 5.53 & 6.77 & 5.39 \\
\hline $\mathrm{C}_{44}$ & 5.81 & 6.12 & 5.79 & 6.29 & 5.76 & 6.62 & 5.68 & 6.59 & 5.63 & 6.95 \\
\hline $\mathrm{C}_{46}$ & 6.67 & 9.40 & 6.44 & 9.78 & 6.46 & 10.88 & 6.25 & 10.14 & 6.18 & 11.13 \\
\hline $\mathrm{C}_{48}$ & 8.73 & 13.13 & 8.65 & 13.48 & 8.20 & 15.02 & 8.01 & 13.73 & 8.01 & 14.87 \\
\hline$C_{50}$ & 11.60 & 16.61 & 11.15 & 17.22 & 11.15 & 18.76 & 10.80 & 16.99 & 10.87 & 18.01 \\
\hline$C_{52}$ & 11.05 & 13.30 & 11.08 & 13.89 & 11.03 & 14.52 & 10.91 & 13.45 & 10.92 & 13.67 \\
\hline $\mathrm{C}_{54}$ & 5.80 & 5.80 & 5.80 & 5.59 & 5.76 & 5.46 & 5.71 & 5.53 & 5.82 & 5.30 \\
\hline
\end{tabular}

${ }^{a}$ Concentrations given in $\mathrm{wt} \%$ of total triacylglycerol content. 
TABLE 7

Triacylglycerol Composition of Separated Suspensions Crystallized in a Rheometer at $26^{\circ} \mathrm{C}$ and Stepwise Melted to Fractionation Temperature ${ }^{a}$

\begin{tabular}{|c|c|c|c|c|c|c|c|c|c|c|}
\hline & $\begin{array}{c}\text { Stearin } 34^{\circ} \mathrm{C} \\
\left(26^{\circ} \mathrm{C}\right)\end{array}$ & $\begin{array}{c}\text { Olein } 34^{\circ} \mathrm{C} \\
\left(26^{\circ} \mathrm{C}\right)\end{array}$ & $\begin{array}{c}\text { Stearin } 32^{\circ} \mathrm{C} \\
\left(26^{\circ} \mathrm{C}\right)\end{array}$ & $\begin{array}{c}\text { Olein } 32^{\circ} \mathrm{C} \\
\left(26^{\circ} \mathrm{C}\right)\end{array}$ & $\begin{array}{c}\text { Stearin } 30^{\circ} \mathrm{C} \\
\left(26^{\circ} \mathrm{C}\right)\end{array}$ & $\begin{array}{c}\text { Olein } 30^{\circ} \mathrm{C} \\
\left(26^{\circ} \mathrm{C}\right)\end{array}$ & $\begin{array}{c}\text { Stearin } 28^{\circ} \mathrm{C} \\
\left(26^{\circ} \mathrm{C}\right)\end{array}$ & $\begin{array}{c}\text { Olein } 28^{\circ} \mathrm{C} \\
\left(26^{\circ} \mathrm{C}\right)\end{array}$ & $\begin{array}{c}\text { Stearin } 26^{\circ} \mathrm{C} \\
\left(26^{\circ} \mathrm{C}\right)\end{array}$ & $\begin{array}{c}\text { Olein } 26^{\circ} \mathrm{C} \\
\left(26^{\circ} \mathrm{C}\right)\end{array}$ \\
\hline $\mathrm{C}_{24}$ & 0.04 & 0.06 & 0.04 & 0.05 & 0.04 & 0.05 & 0.04 & 0.05 & 0.03 & 0.08 \\
\hline Cholesterol & 0.27 & 0.32 & 0.26 & 0.30 & 0.22 & 0.33 & 0.23 & 0.33 & 0.21 & 0.37 \\
\hline $\mathrm{C}_{26}$ & 0.20 & 0.28 & 0.22 & 0.22 & 0.17 & 0.24 & 0.19 & 0.25 & 0.16 & 0.34 \\
\hline $\mathrm{C}_{28}$ & 0.48 & 0.63 & 0.50 & 0.52 & 0.40 & 0.57 & 0.44 & 0.60 & 0.38 & 0.71 \\
\hline $\mathrm{C}_{30}$ & 0.92 & 1.16 & 0.93 & 1.02 & 0.77 & 1.13 & 0.81 & 1.16 & 0.73 & 1.29 \\
\hline $\mathrm{C}_{32}$ & 1.96 & 2.32 & 1.93 & 2.21 & 1.58 & 2.37 & 1.69 & 2.42 & 1.53 & 2.55 \\
\hline $\mathrm{C}_{34}$ & 4.76 & 5.46 & 4.61 & 5.36 & 3.91 & 5.87 & 3.99 & 5.96 & 3.79 & 6.08 \\
\hline $\mathrm{C}_{36}$ & 9.00 & 10.44 & 8.57 & 10.42 & 7.30 & 11.07 & 7.50 & 11.24 & 7.12 & 11.28 \\
\hline $\mathrm{C}_{38}$ & 10.93 & 12.39 & 10.27 & 12.40 & 8.87 & 13.45 & 9.19 & 13.63 & 8.68 & 13.66 \\
\hline $\mathrm{C}_{40}$ & 8.71 & 9.85 & 8.31 & 9.87 & 7.24 & 10.45 & 7.55 & 10.57 & 7.16 & 10.64 \\
\hline $\mathrm{C}_{42}$ & 6.14 & 6.52 & 5.95 & 6.53 & 5.95 & 6.77 & 6.09 & 6.76 & 6.06 & 6.69 \\
\hline $\mathrm{C}_{44}$ & 6.04 & 5.81 & 6.21 & 5.83 & 6.76 & 5.60 & 6.75 & 5.51 & 7.05 & 5.50 \\
\hline$C_{46}$ & 8.00 & 6.88 & 8.30 & 6.95 & 9.73 & 6.13 & 9.39 & 5.98 & 9.93 & 5.91 \\
\hline $\mathrm{C}_{48}$ & 10.62 & 8.98 & 11.29 & 9.10 & 12.93 & 8.03 & 12.48 & 7.91 & 12.98 & 7.78 \\
\hline$C_{50}$ & 13.99 & 11.86 & 14.56 & 12.04 & 15.75 & 10.94 & 15.20 & 10.81 & 15.99 & 10.62 \\
\hline$C_{52}$ & 12.15 & 11.27 & 12.34 & 11.43 & 12.98 & 11.17 & 12.92 & 10.96 & 12.65 & 10.76 \\
\hline$C_{54}$ & 5.78 & 5.76 & 5.72 & 5.77 & 5.41 & 5.84 & 5.58 & 5.85 & 5.56 & 5.75 \\
\hline
\end{tabular}

${ }^{\mathrm{a}}$ Concentrations given in wt $\%$ of total triacylglycerol content.

acids are enriched in the solid fraction, while the contents of the lower-chain fatty acids, as well as the unsaturated fatty acids, are decreased. Tables 4 and 5 show that the difference in the solid fat content of these fractions varies within a standard deviation.

At a final fractionation temperature of $26^{\circ} \mathrm{C}$, greater differences in the triacylglycerol composition (Fig. 6) and fatty acid composition (Tables 8 and 9) occur because more triacylglycerols are separated. The same differences and trends occur as in the $34^{\circ} \mathrm{C}$ fractions. If the temperature equilibrium is reached before separation, the liquid fractions of the slowly cooled suspensions show a melting point at crystallization temperature [measured by conventional DSC and NMR methods $(15,16)]$. All triacylglycerols with a melting point above the crystallization temperature are separated, and the melting characteristics of the liquid fraction are predictable. If supercooled nucleation and stepwise cooling are performed, the differences in the melting points between the liquid fraction and the original milk fat are less significant and are shifted to higher temperatures. This indicates further that, due to cocrystallization, higher-melting triacylglycerols exist in the liquid fractions.

Focusing on other final temperatures, the crystal contents of the suspensions that are crystallized by stepwise cooling and supercooling with a followed stepwise melting, respectively, differ by $2.3 \%$ maximum. These differences are due to compound crystallization that takes place at strong supercooling. The formation of compound crystals also causes differences in the chemical composition of the fractions. If supercooling takes place, the fractionation is less specific. Polymorphism would cause no differences in the solid fat content of a temperature-equilibrated suspension but in the heat of fusion of the crystals. Because no polymorphic transformation takes place on a long time scale, polymorphism

TABLE 8

Fatty Acid Composition of Separated Suspensions Crystallized in a Rheometer at $34^{\circ} \mathrm{C}$ and Stepwise Cooled to Fractionation Temperature ${ }^{a}$

\begin{tabular}{|c|c|c|c|c|c|c|c|c|c|c|}
\hline & $\begin{array}{c}\text { Olein } 34^{\circ} \mathrm{C} \\
\left(34^{\circ} \mathrm{C}\right)\end{array}$ & $\begin{array}{c}\text { Stearin } 34^{\circ} \mathrm{C} \\
\left(34^{\circ} \mathrm{C}\right)\end{array}$ & $\begin{array}{c}\text { Olein } 32^{\circ} \mathrm{C} \\
\left(34^{\circ} \mathrm{C}\right)\end{array}$ & $\begin{array}{c}\text { Stearin } 32^{\circ} \mathrm{C} \\
\left(34^{\circ} \mathrm{C}\right)\end{array}$ & $\begin{array}{c}\text { Olein } 30^{\circ} \mathrm{C} \\
\left(34^{\circ} \mathrm{C}\right)\end{array}$ & $\begin{array}{c}\text { Stearin } 30^{\circ} \mathrm{C} \\
\left(34^{\circ} \mathrm{C}\right)\end{array}$ & $\begin{array}{c}\text { Olein } 28^{\circ} \mathrm{C} \\
\left(34^{\circ} \mathrm{C}\right)\end{array}$ & $\begin{array}{c}\text { Stearin } 28^{\circ} \mathrm{C} \\
\left(34^{\circ} \mathrm{C}\right)\end{array}$ & $\begin{array}{c}\text { Olein } 26^{\circ} \mathrm{C} \\
\left(34^{\circ} \mathrm{C}\right)\end{array}$ & $\begin{array}{c}\text { Stearin } 26^{\circ} \mathrm{C} \\
\left(34^{\circ} \mathrm{C}\right)\end{array}$ \\
\hline Butyric acid & 4.40 & 3.00 & 4.50 & 2.70 & 4.70 & 2.20 & 4.60 & 2.70 & 4.60 & 2.40 \\
\hline Caproic acid & 2.50 & 1.70 & 2.60 & 1.60 & 2.60 & 1.30 & 2.70 & 1.60 & 2.70 & 1.40 \\
\hline Caprylic acid & 1.40 & 1.00 & 1.40 & 0.90 & 1.40 & 0.80 & 1.50 & 0.90 & 1.40 & 0.80 \\
\hline Capric acid & 2.80 & 2.10 & 2.80 & 2.10 & 2.80 & 1.90 & 2.80 & 2.10 & 2.80 & 2.00 \\
\hline Lauric acid & 3.30 & 2.90 & 3.30 & 2.90 & 3.30 & 2.80 & 3.30 & 3.00 & 3.30 & 3.00 \\
\hline Myristic acid & 10.50 & 10.90 & 10.50 & 11.10 & 10.50 & 11.50 & 10.40 & 11.40 & 10.30 & 11.80 \\
\hline Palmitic acid & 27.30 & 33.20 & 27.00 & 34.00 & 26.70 & 35.80 & 26.50 & 33.70 & 26.20 & 35.20 \\
\hline Margaric acid & 0.70 & 0.90 & 0.70 & 0.90 & 0.70 & 1.00 & 0.70 & 0.90 & 0.70 & 0.90 \\
\hline Stearic acid & 10.20 & 15.40 & 9.90 & 15.90 & 9.80 & 17.20 & 9.60 & 15.20 & 9.50 & 16.20 \\
\hline Oleic acid & 25.70 & 19.90 & 26.00 & 19.20 & 26.20 & 17.40 & 26.50 & 19.60 & 27.10 & 17.50 \\
\hline Linoleic acid & 2.00 & 1.60 & 1.90 & 1.60 & 2.00 & 1.50 & 2.10 & 1.60 & 2.10 & 1.30 \\
\hline Linolenic acid & 1.00 & 0.70 & 1.00 & 0.70 & 1.00 & 0.50 & 1.00 & 0.70 & 1.00 & 0.60 \\
\hline Arachidic acid & 0.80 & 0.80 & 0.80 & 0.80 & 0.80 & 0.70 & 0.80 & 0.80 & 0.80 & 0.5 \\
\hline
\end{tabular}

${ }^{a}$ Concentrations given in $\mathrm{wt} \%$ of total fatty acid methyl ester content. 
TABLE 9

Fatty Acid Composition of Separated Suspensions Crystallized in a Rheometer at $26^{\circ} \mathrm{C}$ and Stepwise Melted to Fractionation Temperature ${ }^{a}$

\begin{tabular}{|c|c|c|c|c|c|c|c|c|c|c|}
\hline & $\begin{array}{c}\text { Stearin } 34^{\circ} \mathrm{C} \\
\left(26^{\circ} \mathrm{C}\right)\end{array}$ & $\begin{array}{c}\text { Olein } 34^{\circ} \mathrm{C} \\
\left(26^{\circ} \mathrm{C}\right)\end{array}$ & $\begin{array}{c}\text { Stearin } 32^{\circ} \mathrm{C} \\
\left(26^{\circ} \mathrm{C}\right)\end{array}$ & $\begin{array}{c}\text { Olein } 32^{\circ} \mathrm{C} \\
\left(26^{\circ} \mathrm{C}\right)\end{array}$ & $\begin{array}{c}\text { Stearin } 30^{\circ} \mathrm{C} \\
\left(26^{\circ} \mathrm{C}\right)\end{array}$ & $\begin{array}{c}\text { Olein } 30^{\circ} \mathrm{C} \\
\left(26^{\circ} \mathrm{C}\right)\end{array}$ & $\begin{array}{c}\text { Stearin } 28^{\circ} \mathrm{C} \\
\left(26^{\circ} \mathrm{C}\right)\end{array}$ & $\begin{array}{c}\text { Olein } 28^{\circ} \mathrm{C} \\
\left(26^{\circ} \mathrm{C}\right)\end{array}$ & $\begin{array}{c}\text { Stearin } 26^{\circ} \mathrm{C} \\
\left(26^{\circ} \mathrm{C}\right)\end{array}$ & $\begin{array}{c}\text { Olein } 26^{\circ} \mathrm{C} \\
\left(26^{\circ} \mathrm{C}\right)\end{array}$ \\
\hline Butyric acid & 3.60 & 4.40 & 3.60 & 4.20 & 3.10 & 4.70 & 3.20 & 4.50 & 2.80 & 4.90 \\
\hline Caproic acid & 2.10 & 2.50 & 2.10 & 2.50 & 1.70 & 2.70 & 1.80 & 2.70 & 1.60 & 2.70 \\
\hline Caprylic acid & 1.20 & 1.40 & 1.20 & 1.40 & 1.00 & 1.40 & 1.00 & 1.50 & 0.90 & 1.50 \\
\hline Capric acid & 2.50 & 2.70 & 2.50 & 2.70 & 2.30 & 2.80 & 2.30 & 2.90 & 2.20 & 2.90 \\
\hline Lauric acid & 3.10 & 3.30 & 3.20 & 3.30 & 3.10 & 3.30 & 3.20 & 3.30 & 3.20 & 3.30 \\
\hline Myristic acid & 10.70 & 10.60 & 10.80 & 10.50 & 11.50 & 10.20 & 11.50 & 10.20 & 11.60 & 10.20 \\
\hline Palmitic acid & 29.80 & 27.70 & 29.70 & 27.50 & 32.60 & 26.20 & 32.10 & 26.10 & 32.40 & 26.20 \\
\hline Margaric acid & 0.80 & 0.70 & 0.80 & 0.70 & 0.90 & 0.70 & 0.80 & 0.70 & 0.90 & 0.70 \\
\hline Stearic acid & 12.30 & 10.50 & 12.30 & 10.50 & 14.30 & 9.50 & 13.80 & 9.40 & 14.00 & 9.40 \\
\hline Oleic acid & 23.40 & 25.80 & 23.80 & 25.60 & 20.10 & 27.00 & 20.60 & 27.30 & 20.50 & 26.80 \\
\hline Linoleic acid & 1.80 & 1.40 & 1.90 & 2.00 & 1.50 & 2.10 & 1.60 & 2.10 & 1.70 & 2.00 \\
\hline Linolenic acid & 0.80 & 1.00 & 0.90 & 1.00 & 0.70 & 1.00 & 0.70 & 1.00 & 0.70 & 1.10 \\
\hline Arachidic acid & 0.70 & 0.80 & 0.90 & 0.80 & 0.60 & 0.80 & 0.60 & 0.90 & 0.80 & 0.90 \\
\hline
\end{tabular}

${ }^{a}$ Concentrations given in $\mathrm{wt} \%$ of total fatty acid methyl ester content.

in milk fat crystals cannot be shown but cannot be excluded either.

In conclusion, at controlled temperature conditions without any supercooling below the fractionation temperature, the chemical and physical characteristics of the fractions are significantly different from the original milk fat. If supercooling is performed during crystallization, the crystal amount is increased in the suspensions at a specific fractionation temperature. Even supercooling of $2^{\circ} \mathrm{C}$ at a crystallization temperature of $28^{\circ} \mathrm{C}$ shows a solid fat content increase by $27 \%(7.16$ to $9.50 \%$ solid fat content), compared to a directly crystallized sample. The differences in the triacylglycerol composition and fatty acid composition of these fractions show that compound crystals are formed when supercooling takes place. The differences in the directly detected melting curves of the suspensions, composed of compound crystals, are significant and show narrowed melting ranges. Even though polymorphic transformations cannot be detected over a long period of time, their existence cannot be excluded. In the fractions separated at $34^{\circ} \mathrm{C}$, the solid fat content of the supercooled and not supercooled suspensions is the same, but the melting maximum differs by about $1^{\circ} \mathrm{C}$.

We have shown that even a low or short supercooling of milk fat during crystallization causes formation of compound crystals that show a significantly different chemical composition. For a precise and predictable quality of milk fat frac-

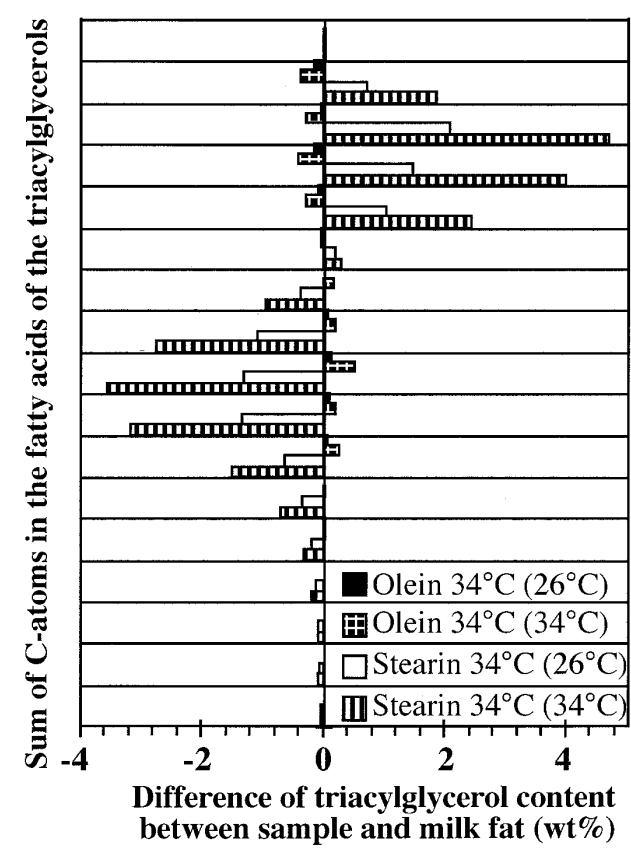

FIG. 5. Differences of the triacylglycerol content between milk fat and the solid or liquid fraction, fractionated at $34^{\circ} \mathrm{C}$, crystallized directly at $34^{\circ} \mathrm{C}$, or by stepwise melting from initial crystallization at $26^{\circ} \mathrm{C}$.

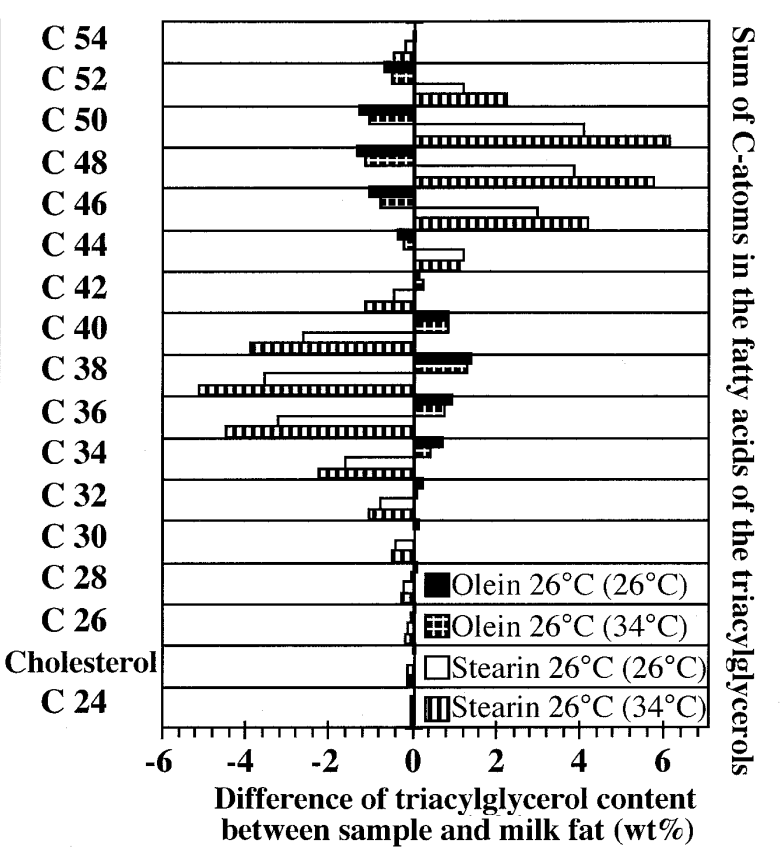

FIG. 6. Differences of the triacylglycerol content between milk fat and the solid or liquid fraction, fractionated at $26^{\circ} \mathrm{C}$, crystallized directly at $26^{\circ} \mathrm{C}$, or by stepwise cooling from $34^{\circ} \mathrm{C}$. 
tions, the temperature has to be controlled and no supercooling should be performed, not even for a short time in the nucleation phase.

\section{ACKNOWLEDGMENTS}

The authors are grateful to M. Collomb and M. Spahni (Federal Dairy Research Institute, Liebefeld, Switzerland) for performing the fatty acid and triacylglycerol measurements. We further thank Spectrospin (Bruker Analytical and Medical Instruments, Fällanden, Switzerland) for putting the NMR at our disposal. The financial and technical support of Tetra Pak (Schweiz) AG, Kloten, Switzerland, is especially acknowledged.

\section{REFERENCES}

1. Jensen, R.G., A.M. Ferries, and C.J. Lammi-Keefe, Symposium: Milk-Fat Composition, Function, and Potential for Change, $J$. Dairy Sci. 74:3228-3243 (1991).

2. Jensen, R.G., Fatty Acids in Milk and Dairy Products, in Fatty Acids in Foods and Their Health Implications, edited by C.K. Chow, Marcel Dekker Inc., New York, 1992, pp. 95-135.

3. Padley, F.B., Occurrence and Characteristics of Oils and Fats, in The Lipid Handbook, edited by F.D. Gunstone, J.L. Harwood, and F.B. Padley, Chapman \& Hall, London, 1994, pp. 147-167.

4. De Man, J.M., and N. Poulsen, Regional Variations in Composition and Properties of Milk Fat, Milchwissenschaft 23:463-467 (1968).

5. Versteeg, C., L.N. Thomas, Y.L. Yep, M. Papalois, and P.S. Dimick, New Fractionated Milkfat Products, Aust. J. Dairy Tech. 49:57-62 (1994).

6. Kreulen, H.P., Fractionation and Winterization of Edible Fats and Oils, J. Am. Oil Chem. Soc. 53:393-396 (1976).

7. Deffense, E., Milk Fat Fractionation Today: A Review, Ibid. 70:1193-1201 (1993).

8. Hamm, W., Trends in Edible Oil Fractionation, Trends Food Sci. Tech. 6:121-126 (1995).

9. Badings, H.T., J.E. Schaap, C. De Jong, and H.G. Hagedoorn, An Analytical Study of Fractions Obtained by Stepwise Cooling of Melted Milk Fat. 1. Methodology, Milchwissenschaft 38:95-97 (1983).
10. Garside, J., General Principles of Crystallization, in Food Structure and Behaviour, edited by J.M.V. Blanshard and P. Lillford, Academic Press, Inc., London, 1987, pp. 35-49.

11. Mortensen, B.K., Physical Properties and Modification of Milk Fat, in Developments in Dairy Chemistry, edited by P.F. Fox, Applied Science Publishers, London, 1983, pp. 159-194.

12. Krautwurst, J., Die Mischkristallisation der Triglyceride, Kieler Milchwirtschaftliche Forschungsberichte 22:255-284 (1970).

13. Walstra, P., Fat Crystallization, in Food Structure and Behaviour, edited by J M.V. Blanshard and P. Lillford, Academic Press, Inc., London, 1987, pp. 67-85.

14. Grall, D.S., and R.W. Hartel, Kinetics of Butterfat Crystallization, J. Am. Oil Chem. Soc. 69:741-747 (1992).

15. Solid Content Determination in Fats by NMR (Low resolution nuclear magnetic resonance), International Union of Pure and Applied Chemistry, 1991, pp. 59-61.

16. Breitschuh, B., and E.J. Windhab, Direct Measurement of the Thermal Fat Crystal Properties for Milk Fat Fractionation, $J$. Am. Oil Chem. Soc. 73:1603-1610 (1996).

17. Collomb, M., and M. Spahni, Triglyceride: Gas-Chromatographische Bestimmung in Milchfett, Federal Dairy Research Institute, Liebefeld, Switzerland, 1996, pp. 1-11.

18. Grob, K., H.P. Neukom, and R. Battaglia, Triglyceride Analysis with Glass Capillary Gas Chromatography, J. Am. Oil Chem. Soc. 57:282-286 (1980).

19. Frede, E., and H. Thiele, Analysis of Milkfat by HPLC, Ibid. 64:521-528 (1987).

20. Woodrow, I.L., and J.M. de Man, Polymorphism in Milk Fat Shown by X-Ray Diffraction and Infrared Spectroscopy, $J$. Dairy Sci. 51:996-1000 (1968).

21. Sherbon, J.W., Crystallization and Fractionation of Milk Fat, AOCS 46th Annual Fall Meeting, Ottawa, Ontario, Canada, 1974, pp. 22-25.

22. Zhao, J., and D.S. Reid, Thermal Studies on the Crystallization Kinetics of Triglycerides and Milkfat by DSC, Thermochimica Acta 246:405-416 (1994).

23. van Berensteyn, E.C.H., Polymorphism in Milk Fat in Relation to the Solid/Liquid Ratio, Neth. Milk Dairy J. 26:117-130 (1972).

[Received July 14, 1997; accepted December 2, 1997] 